\title{
Coping with the first fail: a strategic approach to student retention
}

Simon M. Smith, University of Central Lancashire

Andrea Lee, University of Central Lancashire

\begin{abstract}
This article presents the findings of a pilot study conducted to tackle student attrition within year 1 undergraduate business school programmes. The approach tracks across a year of study 13 Accounting and Finance students (the business programmes with distinctly the worst attrition statistics) from a cohort of 92 who failed their very first assessment in higher education. A variety of interventions were used within an action research approach, including interviews, coaching and general academic skills support classes. 12 of these 13 'at risk' students successfully passed their year of study and continued their studies within the institution. Ultimately, the study presents an alternative and strategic micro-level approach that could prove useful in the continuous efforts towards improving student retention.
\end{abstract}

Keywords: Student retention; undergraduate learning; coaching.

\section{Introduction}

It is a truism to state that student retention is of considerable importance within higher education. Indeed, this has become an increasingly important issue now the University of Central Lancashire will be charging UK and other European students $£ 9000$ a year in tuition fees from 2012. This article reports on a micro-level project in Lancashire Business School that focused on one key element within retention - the failure of the very first assessment in higher education. Following a brief overview of literature on the surrounding subject area, and an outline of the research methods used, the results and future considerations are presented.

\section{The war on attrition}

'Students now arrive at college less well prepared than they once did. They often lack solid basic skills ... many students lack confidence ... most faculty quickly agree that teaching college students today is far more challenging than it once was' (Weimer, 2002, p.95-96).

This quotation effectively summarises much of today's struggle with student attrition. Crosling et al. 's (2009) research highlights that a student may leave university for a large variety of reasons, and they go on to suggest that it is rarely just one reason why students leave. Christie $e t$ al. (2004) argue it is not just academic weakness that leads to attrition; it is a complex range of internal and external factors. Nevertheless, Yorke and Longden (2004, 2007, 2008), within a number of large studies, offer prominent commonalities in relation to student attrition:

- Students can make flawed decisions when entering a degree programme; 
- Students can have negative perceptions relating to experience within a programme and the institution generally;

- Students can fail to cope with the demand of the programme;

- Events outside of the institution can impact on a student's life.

\section{The 'First Fail' approach}

Linking to Yorke and Longden's $(2004,2007,2008)$ findings above, the 'First Fail' project concentrates on a 'student's failure to cope with the demand of the programme'. The research sample group used specifically relates to the Accounting and Finance degree programmes. These were chosen for the pilot study because they had notoriously high failure rates and significantly low retention rates (just under $60 \%$ in year 1 at their very worst) within the institution. The main reason for this was felt to be the affiliation with an additional professional accreditation that dictates much of the course content and leaves little opportunity to build support areas into the programmes (e.g. skills modules). In addition, entry requirements have slowly been increased over time to help reduce attrition, but it is realised there is conflict between raising these requirements and maintaining student numbers. Thus, a proactive and innovative approach that helps to increase student achievement and assist with higher education transition was welcomed by the school. Here is an overview of the project's action research approach:

- A sample group of year one Accounting and Finance students who failed their very first assessment attempted in higher education were identified. The assessment was an in-class test. Of the 92 students registered, 18 failed and another 14 did not attend.

- Attempts were made to contact all 18 of the students that failed via email and telephone. 13 of the 18 were successfully contacted and interviewed one-to-one to explore the reasons given for, and impact of, initial failure.

- All 13 interviewees were offered one-to-one academic coaching sessions. 7 students participated in these sessions with the view of enhancing their academic skill and developing ownership for potential solutions.

- A series of general support classes were offered to all students on the particular module identified. The students who failed and did not attend the in-class test were especially encouraged to attend.

\section{The coaching angle}

With coaching being a unique approach adopted in this research project, a basic understanding of the concept is presented here. The approach used encourages the coachee to acquire the solutions to problems by themselves; the coach merely stimulates this acquisition (Whitmore, 2009). In other words, 'Coaching is unlocking people's potential to maximise their own performance' (Gallwey, cited in Whitmore, 2009, p.10). Indeed, Swartz et al. (2005, p.647) argue that 'Coaching is a useful complement to academic advising'.

\section{Results}


12 of the 13 students interviewed (including 6 of the 7 who were coached) successfully passed the module by the end of the year and progressed onto year 2 after initially failing their very first assessment. The result is very encouraging considering that these students were labelled 'at risk' of dropping out because of this initial academic experience.

Feedback from students on the coaching sessions was particularly positive:

'I know all about revision, but now I've thought about it properly.'

'Never had time to think about this or talk to anybody about it.'

'Glad I came today and discussed ways to change.'

The initial 13 interviews helped to guide the content within the support classes. This proved very valuable in terms of direction and relevance for students. In particular, students wanted and needed help with generic academic skills, course terminology, and example explanation and practice. With the input of module tutors, significant guidance within these areas was provided by an academic support tutor. The support classes had a wide reaching impact on the module in general:

- The module pass rate at the end of the year had risen significantly from $81 \%$ in 2007-08 and $79 \%$ in $2008-09$ to $87 \%$ for $2009-10$.

- In addition, the average grade of those that attended the support classes (34 students from a total of 103) was $71 \%$ compared to $62 \%$ across the entire cohort for that year.

It is realised that other factors could have contributed towards this success, but it strongly felt that the student support classes, interviews and coaching played a pivotal role.

Finally, it was known that the school had achieved its overall target for an increase of $3 \%$ for retention on year 1 business programmes and that the interventions within Accounting and Finance were a significant bulk of that figure. Unfortunately, access to key statistics is unavailable within this report as the main author changed roles within the institution and is no longer privy to such information.

\section{Future considerations}

'Students are more likely to succeed when they find themselves in settings that are committed to their success ... provide needed academic and social support, give frequent feedback and actively involve them' (Tinto, 2005, p.94).

The focus used within this micro-level project highlight possibilities for addressing student retention in the future. The concentration on a 'student's failure to cope with the demand of the programme' appears to have reaped great reward. Thus, it is recommended that this academic focus on students failing their first assessment could be a useful angle for addressing problems of student attrition. In particular, teaching staff may find it productive: to interview failing students 
(perhaps through personal tutoring) to understand the individual gaps in academic ability; to apply coaching techniques to empower students towards solving problems by themselves; and to create directed support classes (including extended help on generic academic skills, course terminology and practical examples) that further assist with student transition into higher education and provide a valuable setting that students can tap into. The strategic process applied within this project also provided an opportunity to open up a dialogue and revisit assessment approaches with a view to preventing failure in the future, rather than simply curing it. With the increasing pressures generated from rises in student fees, individualised student interventions, such as the ones highlighted in this report, could provide perceived added value to student experiences.

As a note of caution, it is reemphasized that this article provides one focus within a complex amalgam of factors influencing student retention.

\section{References}

Christie, H., Munro, M. and Fisher, T. (2004) 'Leaving university early: exploring the differences between continuing and non-continuing students'. Studies in Higher Education. 29 (5): 617-636.

Crosling, G., Heagney, M and Thomas, L. (2009) 'Improving student retention in higher education: improving teaching and learning'. Australian Universities' Review. 51 (2): 9-18.

Swartz, S.L., Prevatt, F. and Proctor, B.E. (2005) 'A coaching intervention for college students with Attention Deficit/Hyperactivity Disorder'. Psychology in the Schools. 42 (6): 647-656.

Tinto, V. (2005) 'Reflections on retention and persistence: Institutional actions on behalf of student persistence'. Studies in Learning, Evaluation Innovation and Development. 2 (3): 89-97.

Weimer, M. (2002) Learner-Centered Teaching: Five Key Changes to Practice. San Francisco: Jossey-Bass.

Whitmore, J. (2009) Coaching for Performance: GROWing Human Potential and Purpose. Fourth edition. London: Nicholas Brealey Publishing.

Yorke, M. and Longden, B. (2004) Retention and Student Success in Higher Education. Maidenhead: McGraw-Hill Education.

Yorke, M. and Longden, B. (2007) The First-Year Experience in Higher Education in the UK: Report on Phase 1 of a Project Funded by the Higher Education Academy. Heslington: The Higher Education Academy.

Yorke, M. and Longden, B. (2008) The First-Year Experience in Higher Education in the UK: Final report. Heslington: The Higher Education Academy. 


\section{About the authors}

Simon Smith is a Senior Lecturer in International Business Communication within the School of Language, Literature and International Studies at the University of Central Lancashire.

Email: $\underline{\text { SMSmith1@uclan.ac.uk. }}$

Andrea Lee is a Principal Lecturer and Senior Tutor within Lancashire Business School at the University of Central Lancashire.

Email: $\underline{\text { AMLee@uclan.ac.uk }}$ 